\title{
AN INFORMAL FRANCO-DUTCH ALLIANCE: TRADE AND DIPLOMACY BETWEEN THE MASCARENES AND THE CAPE, 1719-1769
}

\section{Rafaël Thiébaut}

To cite this article: Thiébaut, Rafaël. "An Informal French-Dutch Alliance: Trade and Diplomacy Between the Cape Colony and the Mascarenes, 1719-1769." Journal of Indian Ocean World Studies, 1 (2017), pp. 128-147.

More information about the Journal of Indian Ocean World Studies can be found at: jiows.mcgill.ca

(C) Rafaël Thiébaut. This is an Open Access article distributed under the terms of the Creative Commons License CC BY NC SA, which permits users to share, use, and remix the material provide they give proper attribution, the use is non-commercial, and any remixes/transformations of the work are shared under the same license as the original. 


\title{
An Informal Franco-Dutch Alliance: Trade AND Diplomacy Between The MAscarenes AND THE CAPE, 1719-1769
}

\author{
Rafaël Thiébaut \\ Université Paris I - Panthéon-Sorbonne \& Vrije Universiteit Amsterdam
}

\begin{abstract}
In the eighteenth century, possessions of the different European mercantilist companies rarely interacted, commercially or otherwise. For example, communication between the Dutch colony at the Cape and the French Mascarenes under the regime of the Compagnie des Indes was mostly fortuitous. However, when the French islands were in need of provisions during the Seven Years' War (1756-1763), local authorities did not hesitate to establish a direct maritime connection with the Dutch Cape Colony in order to obtain wheat and wine. Throughout the conflict, the governors of the two colonies maintained a regular and friendly correspondence to ensure such a significant flow of provisions from the Cape to the Mascarenes that the latter became the Cape's most important foreign trading partner.
\end{abstract}

1757 was a year of tough choices for René Magon de la Villebague (1722-1778), governor of the French Mascarene Islands from 1755-9. First, the Île de France (Mauritius) and Bourbon (Réunion) experienced a smallpox epidemic in which a quarter of the population died. ${ }^{1}$ At the same time, as a state of war existed between England and France, they were expected, even though the islands suffered from chronic food shortages, to provision a large French fleet rumoured to be sailing to Port Louis, capital of the Ile de France, en route to Pondicherry. Magon, who had just received a vessel from the Cape loaded with wheat, had to redouble his efforts to ensure that provisions continued to flow to the Mascarenes from the neutral Dutch establishment. For this reason, it is likely that he sent Tulbagh, the governor of the Cape and a great amateur botanist, a gift of coffee plants and ebony wood seeds:

1. Bibliothèque nationale de France (hereafter BNF), Nouvelles acquisitions françaises (NAF), 9147, f. 139-140, Cossigny to Dupleix, Ile de France, October 1, 1756. 
That, I have been assured, will bring you pleasure : accept these trifles, Monsieur, as a pledge of the friendship that I am very flattered to see well established between us, the good understanding of our two nations is a new link which must tighten the knot [of friendship]. ${ }^{2}$

Thus began a crucial albeit informal alliance between the French colonial authorities on the Mascarenes and the Dutch at the Cape.

\section{INTRODUCTION}

In the eighteenth century, the European presence in the Indian Ocean region was largely limited to the administrative, commercial, and military personnel of coastal settlements. The Cape and the Mascarenes differed from these, resembling more closely European plantation colonies in the Caribbean where white settlers dominated large slave populations of Afro-Asian origin. Although only 30 to 40 days of sailing time separated Port Louis from Table Bay, relations between the Mascarenes and the Cape were limited due to the mercantilist character of European trading companies which ensured that they maintained chiefly intra-colonial rather than inter-colonial relations. Indeed, from the mid-seventeenth century, Franco-Dutch relations were characterized by conflict and their interaction in the Indian Ocean by imperial rivalry. Amicable exchanges between the two were virtually non-existent until the middle of the eighteenth century.

In the early modern period, the Indian Ocean World (IOW) was a crossroads, a meeting place of different cultures. Nevertheless, conventional historiography reflects a somewhat nationalistic approach; while much has been written about the different European companies active in the Indian Ocean, and the political interests driving them, scholars have tended to focus on a single company rather than analyze them as related phenomena. In addition, they have emphasized the mercantilist and insular character of each European empire. ${ }^{3}$ Scholars have researched issues of political and economic rivalry to a greater extent than cooperation between the different empires, and there is an absence of microhistories. However, while individual European stations in the IOW have been seen through metropolitan eyes as relatively static entities, they necessarily had to engage in some local initiative in order to overcome day-to-day problems. ${ }^{4}$

Probably the greatest amount of research on eighteenth-century European colonization in the IOW has focused on the Dutch colony at the Cape. ${ }^{5}$ This is thanks to the

2. Western Cape Archives (hereafter WCA), C652, without folio, Magon to Tulbagh, Ile de France, October $31,1757$.

3. See K.N. Chaudhuri, Trade and Civilization in the Indian Ocean (Cambridge: Cambridge University Press, 1985).

4. R. Barendse, The Arabian Seas, 1700-1763 (Leiden: Brill, 2009), 4:1602-1630.

5. Richard Elphick \& Hermann Giliomee, The Shaping of the South African Society: 1652-1820 (Cape 
exceptional abundance of archival material about the Cape, and Dutch scholarly interest in the history of their former colony. The French presence on Mauritius has also been well documented, and for similar reasons. ${ }^{6}$ The main historical foci in both regions have been political (the changes of regimes) and social history. ${ }^{7}$ Only recently have researchers of the Indian Ocean region started to focus on intra-regional, namely commercial and cultural interactions, between Europeans and local populations, and on slavery and the slave trade. ${ }^{8}$

It is against this background that this article helps break new ground in analyzing the interconnections within and across the French and Dutch empires in the IOW, and the formation of global imperial networks. ${ }^{9}$ Although historians have noted the existence of relations between the Dutch and French colonial empires during the Seven Years' War, we lack real insight into the nature of their interactions. ${ }^{10}$ Much can be learned from analyzing the dynamics of these exchanges, as other work on networks in the IOW has shown. ${ }^{11}$ Although this article focuses on a single event, it does so in the context of a growing Franco-Dutch commercial relationship, and its wider socio-economic and political consequences. It draws primarily on research into primary sources in the Western Cape Archives, Cape Town and the Archives Nationales d'Outre-mer, Aix-enProvence (ANOM). The latter houses the very rich $\mathrm{C} 4$ series which contains detailed documents on divergent subjects concerning the history of the southwest Indian Ocean region, most importantly slavery. ${ }^{12}$ Due to conservation issues, very few documents from the Compagnie des Indes regime remain intact in the National Archives of Mauritius. However, the Nationaal Archief at The Hague, the Western Cape Archives in Cape Town, and multiple archives in France have provided important additional information on the subject, especially the letters and the personal journals of two governors of the

Town: Longman, 1979).

6. Auguste Toussaint, Histoire de l'île Maurice (Paris: Presses universitaires de France, 1971).

7. Nigel Worden, Slavery in Dutch South Africa (Cambridge: Cambridge University Press, 1985); Richard B. Allen, "The constant demand of the French: The Mascarene Slave Trade and the World of the Indian Ocean and Atlantic during the Eighteenth and Nineteenth Centuries," Journal of African History 49, no. 1 (2008): 43-73.

8. See Gwyn Campbell, ed., The Structure of Slavery in Indian Ocean Africa and Asia (London: Frank Cass, 2004).

9. See Stephen Howe, "Introduction”, in The New Imperial Histories Reader, ed. Stephen Howe (London, Routledge, 2010), 1-20.

10. Daniel Baugh, The Global Seven Years' War, 1754-1763: Britain and France in a Great Power Contest (New York: Longman, 2011), 475; Jonathan R. Dull, The French Navy and the Seven Years' War (Lincoln: University of Nebraska Press, 2005), 153.

11. See Teotonio R. de Souza, "French Slave-Trade in Portuguese Goa (1773-1791)" in Essays in Goan History, ed. Teotonio R. de Souza (New Delhi: Concept Pub. Co., 1989), 119-131.

12. Thomas Vernet, et al., Inventaire sélectif sur l'esclavage / Select Guide to Sources on Slavery from the Archives Nationales de France. Fonds Colonies C4, correspondance à l'arrivée, Ile de France (1714-1810), 1 (Réduit \& Port Louis: University of Mauritius Press, 2011). 
Mascarenes, René Magon de la Villebague and Antoine Marie Desforges-Boucher. In this article, we have used these primary sources to study the important political and commercial interactions between the Mascarenes and the Cape, especially during the Seven Years' War. Although for most historians, the "French period at the Cape"13 came later, from 1781 to 1783 when French troops were stationed at the Cape in order to defend it from English aggression, significant numbers of French warships called at the Cape during previous conflicts, some remaining there for several months in order to take advantage of good local harvests. These exchanges, we argue, benefitted not only the French, it also had a significant economic impact on Cape and its inhabitants.

This article first provides an overview of Franco-Dutch rivalry in the IOW between the early seventeenth and late eighteenth centuries. Second, it examines in turn the first interactions between the Dutch colony at the Cape and the French Mascarenes, and the outbreak of war which increased direct relations between the two colonies. The driving forces behind this rapprochement were, on the French islands, chronic food shortages and isolation from the metropolis and, at the Cape, the prospects of commercial profit that this offered. We conclude by detailing the impact of the French presence at the Cape during this period of cordial relations, and of post-conflict inter-colonial relations.

\section{Early Franco-Dutch Contact in The Indian OCEAN World}

From 1595 the Dutch, following the example of the Portuguese and English, started trading expeditions to the East Indies. ${ }^{14}$ Within a few years, they founded the Verenigde Oost-Indische Compagnie (Dutch East India Company or VOC), which until the end of the eighteenth century held a monopoly of Dutch trade in the IOW. The French, who sporadically voyaged into this region in the first half of the seventeenth century, established their first serious commercial venture there from the 1640s with the founding of Fort Dauphin, on the southeast coast of Madagascar. ${ }^{15}$ This was a relatively modest accomplishment compared to the commercial empire the VOC had by then established and which, following the conquest of the Moluccas (the Spice Islands) in 1605, and the foundation fourteen years later of Batavia, on the island of Java, as their regional capital, focused predominantly on the East Indies.

In 1638, the Dutch also established themselves on the uninhabited island of Mauritius, chiefly to exploit its sources of ebony. From there, they started a modest trade with the east coast of Madagascar, where they encountered some French outposts. ${ }^{16}$ In

13. Andrew B. Smith, "The French Period at the Cape, 1781-1783: A Report on Excavations at Conway Redoubt, Constantia Nek," Military History Journal 5, no.3 (1981): 107-113.

14. Willem Lodewycksz, De Eerste Schipvaart der Nederlanders naar Oost-Indië onder Cornelis de Houtman, 1595-1597 (The Hague: Nijhoff, 1915).

15. This outpost existed from 1643 until 1674.

16. See Nationaal Archief (hereafter NA), VOC, 1162, f. 351-356, Van der Meersch to the Heren XVII, 
1648, the French took control of the island of Bourbon, and four years later, the VOC founded a refreshment station for their ships at the Cape of Good Hope. For both nations, these establishments in the southwest Indian Ocean were somewhat peripheral, far from the Indian peninsula and other thriving commercial regions in the IOW. Interactions between representatives of the different European countries initially remained limited to isolated encounters at sea or in some Asian ports. This changed with the creation in 1664 of the Compagnie française pour le commerce des Indes orientales (French East India Company - hereafter Compagnie), modelled on the VOC, and Louis XIV's ambition to challenge Dutch commercial supremacy in the IOW (see Figure 1). ${ }^{17}$

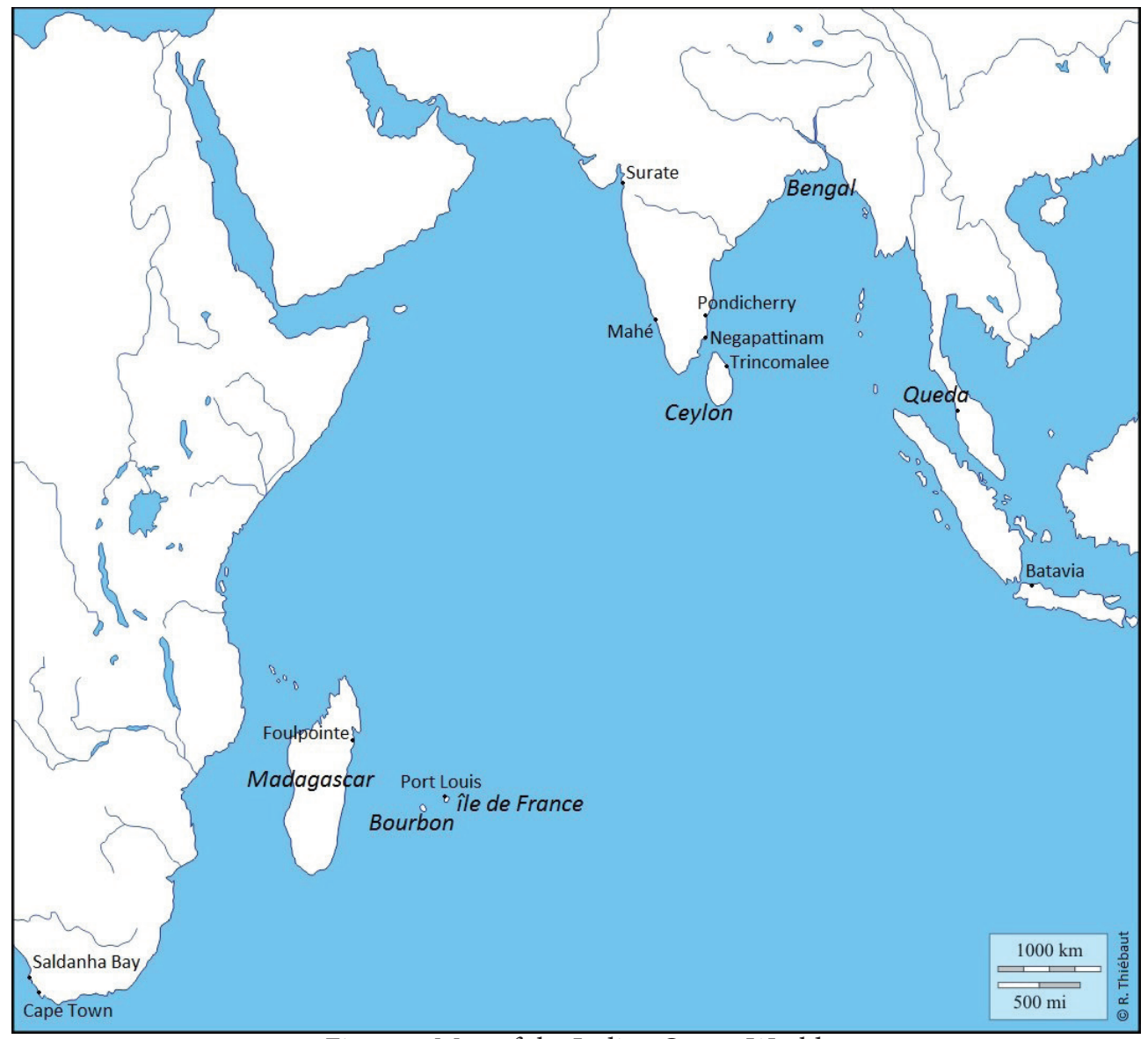

Figure 1. Map of the Indian Ocean World.

The half century from 1664 was largely characterized by commercial clashes and military conflicts between the Dutch and French that inevitably spread to the Indian Ocean. French naval squadrons failed in their attempts to establish colonies in Saldanha Bay in 1666 and Trincomalee in 1672, and two years later at San-Thomé (Mylapore) the Dutch fleet 
destroyed that of Vice Admiral De La Haye. ${ }^{18}$ However, the Dutch failed to prevent the acquisition of Pondicherry in 1674 by François Martin, a former servant of the VOC who became the first governor of the French Indian territories. There followed a short period of peace until the late 1680s when war again erupted between the two countries. French privateers effectively disrupted Dutch commerce in the region and although the VOC captured Pondicherry in 1693 they handed it back to the French in 1699. The outbreak of the War of the Spanish Succession (1701-1713) intensified privateering, and the Dutch lost many ships to French squadrons. ${ }^{19}$ Nevertheless, French possessions in the IOW remained relatively modest, being limited to Pondicherry, Bourbon, and some factories in Surat and Bengal until the close of the war and the creation in 1719 of the Compagnie Perpétuelle des Indes Orientales. This new company inherited the French possessions in the Indian Ocean and was, like the VOC, granted a monopoly on trade in the IOW. Far more interested in commerce than its predecessor had been, it took advantage of thirty years of peace until 1744 to expand its trading interests in India, and to colonize Mauritius, renamed Île de France, which the Dutch had abandoned in $1710^{20}$ and which, together with the neighbouring Island of Bourbon, was intended as a refreshment station for French ships, just as the Cape was for VOC ships. ${ }^{21}$

\section{First Interactions Between the Two Colonies}

Franco-Dutch relations in the IOW were traditionally characterized by hostility. As late as the 1720s, some Frenchmen thought that Pasques de Chavonnes (1654-1724), governor of the Cape from 1714 to 1721 , was poised to forcibly retake the Île de France. ${ }^{22}$ Imperial rivalry was also marked by commercial competition. Initially, there were no direct relations between the Dutch Cape and the French Mascarenes due to their secondary importance to the Dutch East Indies and French settlements in South Asia respectively. The French had their capital on the Indian peninsula (Pondicherry) where their commercial interest focused on textiles, while the Dutch from Batavia concentrated on the East Indies spice trade. ${ }^{23}$ French ships occasionally called at the Cape, but only for provisions.

18. Maurice Boucher, The Cape of Good Hope and Foreign Contacts, 1735-1755 (Pretoria: University of South Africa, 1985), 33-35.

19. WCA, C386 \& C390, without folio, Reports on the taking of the Overwinnaar in 1708 and the Schoonauwen in 1711.

20. Megan Vaughan, Creating the Creole Island: Slavery in Eighteenth-Century Mauritius (Durham \& London: Duke University Press, 2005), 18-20.

21. Nigel Worden, "Cape Town and Port Louis in the Eighteenth Century," in The Indian Ocean Rim: Southern Africa and Regional Co-operation, ed. Gwyn Campbell (London: Routledge-Curzon, 2003), 41. 22. Archives départementales de La Réunion (hereafter ADLR), Compagnie des Indes, C19, without folio, Directors of the Company to Desforges-Boucher, Paris, April 23, 1723.

23. Philippe Haudrère, Les Compagnies des Indes orientales: Trois siècles de rencontre entre Orientaux et Occidentaux (Paris: Ed. Desjonquères, 2006); F.S. Gaastra, De Geschiedenis van de VOC: Opkomst, bloei 
However, Cape-Mascarene relations witnessed a dramatic change following the installation of Mahé de La Bourdonnais (1699-1753) as governor of the Mascarenes in 1735. He oversaw a major restructuring of the economies of the Île de France and Bourbon. He used returning Compagnie ships to import slaves from Madagascar, Mozambique, and India in order to augment the labour force and therefore the agricultural output of the Île de France and Bourbon. He also transformed Port Louis into a "respectable naval base." This, together with growing French trade in the IOW, resulted in an increase in the number of French vessels calling at the Cape. ${ }^{25}$ During the War of Austrian Succession (17448), when France and the Dutch Republic formally declared hostilities, La Bourdonnais concentrated his attention on English possessions in India and largely ignored the VOC, which he saw as a declining power. ${ }^{26}$ While VOC authorities at the Cape tried to remain neutral, and in 1748 were obliged to give logistic support to their English allies against the Mascarenes, the number of French vessels docking in Table Bay declined sharply. However, after the war, Franco-Dutch maritime trade recovered, and between 1748 and 1755, 34 French East India ships called at the Cape, representing a 10 to 21 percent increase in the French proportion of foreign ships calling there. ${ }^{27}$ That French vessels were well treated is attested to in a letter of thanks, dated October 1752, sent by Charles Godeheu (1708-1764) director of the Compagnie in Paris, to the governor of the Cape. ${ }^{28}$

In December 1743, La Bourdonnais sent a ship, the Triton, to the Cape with two letters. The first requested the purchase of wine for the Mascarenes in return for ebony wood, coffee, tobacco, and Spanish piastres. The second, much bolder, proposed to Dutch governor Hendrik Swellengrebel (1700-1760) a trade agreement whereby the Cape would annually supply the Mascarenes with 500 to 600 barrels of wine in exchange for ebony. ${ }^{29}$ Although the Cape authorities were eager to accept the first proposal as being "beneficial and without inconveniency for the Company [VOC]," they refused the second. ${ }^{30}$ Nevertheless, this constituted the first formal direct contact between the authorities of the two colonies.

Agriculture on the Mascarenes also developed under La Bourdonnais, but in a quite differentl way to that of the Cape. As early as the 1720s, a plantation economy similar to that of the Caribbean islands had emerged on the Île de France where planters focused

en ondergang (Zutphen: Uitgevermaatschappij WalburgPers, 2009).

24. Dureau Reydellet, Mahé de La Bourdonnais : gouverneur des Mascareignes (Saint-Denis: Editions CNH 1993), 19-27.

25. Boucher, The Cape of Good Hope and Foreign Contacts, 52.

26. Archives nationales d'outre-mer (hereafter ANOM), COL/C4/2, without folio, La Bourdonnais to the Minister of the Navy, Île de France, December 20, 1736,

27. Pieter Van Duin \& Robert Ross, Economy of the Cape Colony in the Eighteenth Century (Leiden: Centre for the History of European Expansion, 1987), 127.

28. WCA, C651, without folio, Godeheu to Tulbagh, Lorient, October 13, 1752.

29. NA, VOC 4157, f. 101-102, La Bourdonnais à Swellengrebel, Île de France, December 7, 1743.

30. WCA, C122, f. 56-67, Resolution of the Council of Policy, January 28, 1744. 
largely on sugar, cotton, and indigo, as well as ebony wood, and relied on Bourbon, which also produced significant amounts of coffee, for grain. ${ }^{31}$ However, due to systematic Compagnie discouragement of subsistence agriculture, the Mascarenes failed to produce enough food to feed its growing number of mostly servile inhabitants, let alone supply passing ships. ${ }^{32}$ La Bourdonnais tried to ensure that sufficient land was reserved for the growing of basic food crops and to maintain cattle herds-but with little success. ${ }^{33}$

In order to overcome the lack of self-sufficiency in provisions, the Mascarenes sent ships on a frequent basis to the east coast of Madagascar, primarily to Foulpointe, in order to obtain rice, livestock, and salted beef, as well as slaves. Pondicherry and Bengal also regularly sent rice to the Mascarenes, and the island of Rodrigues provided tortoises. Nevertheless, food on the Mascarenes was often in short supply. As Rose Pinczon du Sel (1730-1824) ${ }^{34}$ wrote in 1753: "We lack everything on Mauritius [Île de France]. There are no bullocks, sheep, calves or flour. Hunting is forbidden, subject to major punishment. The population live on rice and fish. Poultry can only be had at an exorbitant price." 35 The same year, she noted in another letter, "The cost of living is very high, and even money cannot buy everything"36

By contrast, land at the Cape was devoted entirely to growing food crops. In the first half of the eighteenth century, the output of wheat and wine increased sufficiently to provision passing VOC and foreign ships and send annual cargoes of wheat to Batavia, Negapattinam, and even to the Netherlands. ${ }^{37}$ However, in the 1750s, the Cape experienced an economic slump that was due chiefly to the highly centralized structure of the VOC. Each year, the company Directors in the Netherlands, the Heren XVII (the Lords Seventeen), sent directives to the Governor of the Cape and his Council. ${ }^{38}$ All commerce was in the hands of the company and the inhabitants of the Cape had to cultivate a certain quota of crops that the VOC purchased at low fixed prices. The

31. Pierre Crépin, Mahé de La Bourdonnais, Gouverneur-Général des Iles de France et de Bourbon, 16991753 (Paris: Editions Leroux, 1922), 70-75.

32. Service historique de la Défense à Brest, Dossier 92, Mémoire sur l’Ile de France, 1770.

33. Crépin, Mahé de La Bourdonnais, 75-77.

34. In 1752, Marie-Rose Courtoys de La Ville Asselin follows her husband Vincent-Paul Pinczon du Sel to make fortune on the Mascarene Islands.

35. Letter of Rose Pinczon du Sel to La Rochedurand, Mauritius, 17.05.1753. Béatrice de Boisanger \& Bernard de La Bourdonnaye-Blossac, eds., Fortune des isles: lettres et souvenirs de l'Isle de France (La Rochelle: Découvrance, 2008), 43-45.

36. Letter Rose Pinczon du Sel to Madame Courtoys, Ile de France, 01.09.1753. Boisanger \& La Bourdonnaye-Blossac, Fortune des Isles, 43-45.

37. Jan Van Riebeeck, Journal of Jan van Riebeeck (Cape Town: Van Riebeeck Society, 1952), 1:234; WCA, C138, f. 165-170, Resolution of the Council of Policy, February 13, 1760; Van Duin \& Ross, Economy of the Cape Colony, 16-18.

38. Gerrit Schutte, "Company and colonists at the Cape, 1652-1795," in Shaping the South-African Society: 1652-1840, ed., R. Elphick et al. (Connecticut: Wesleyan University Press, 1989), 177-182. 
Council at the Cape decided whether or not to sell company grain to foreign ships, but generally, if supplies were abundant, and a reasonable price offered, would not refuse. ${ }^{39}$

However, the VOC maintained a commercial monopoly despite the petitions of local Dutch settlers in 1719 and 1732 to grant them the right to trade privately. ${ }^{40}$ The settlers were also resentful of the heavy stamp duties imposed on imported and exported products like wheat and wine. ${ }^{41}$ Nevertheless, La Bourdonnais' proposal in 1743 to encourage trade between the Cape and the Mascarenes persuaded the VOC to modify its regulations and, in 1746, Cape residents were permitted to buy Mauritian ebony from French ships calling there. ${ }^{42}$ Around the same time, Cape wine also started to be sold to foreign ships, French Mascarene vessels appearing to constitute the most important buyers. ${ }^{43}$ Such trade increased significantly from the start of war in the 1750 s. The situation was different on the Mascarenes, where the governor had more freedom to act. For a few years, he authorized private trade for Mascarene settlers, albeit within Compagnie regulations. ${ }^{44}$ Further, although some "pacotille" [goods that ship officers were authorized to trade on their private account] was authorized in limited quantities for naval officers, it soon developed into an important contraband trade. ${ }^{45}$ La Bourdonnais' trade proposal would certainly have raised some eyebrows in Lorient, headquarters of the Compagnie in France, but because of the pressing need in the Mascarenes for provisions and European supplies, no effective action was taken against it.

\section{WAR AND Diplomacy}

The outbreak of the Seven Years' War in 1756 between England and France placed the Dutch Republic in a delicate position. Although multiple defense treaties bound them to the English, the Dutch were very anxious about the rising naval power of their ally and the commercial competition this posed. During the War of the Austrian Succession (1744-1748), the Dutch had also been witness to the ineffectiveness of the barrier system

39. WCA, C134, f. 502-511, Resolution of the Council of Policy, December 10, 1756.

40. WCA, C1485, without folio, Council of Policy to Directors of the VOC, Cape of Good Hope, March $13,1732$.

41. Nicolas-Louis de La Caille, Travels at the Cape 1751-1753: an annotated translation, trans. and ed. R. Raven-Hart (Cape Town: A.A. Balkema, 1976), 3; François Bernard, Afrique hollandaise, ou tableau historique et politique de l'état originaire de la Colonie du Cap de Bonne-Espérance Comparé avec l'état actuel de cette colonie, (Holland: 1783), 202.

42. Boucher, The Cape of Good Hope and Foreign Contacts, 47.

43. ANOM, COL/C4/6, without folio, David to the Directors of the Compagnie, Ille de France, November 8, 1750; Van Duin \& Ross, Economy of the Cape Colony, 52-53.

44. Between 1742 and 1747, reestablished in 1754. Haudrère, Les Compagnies des Indes orientales, 1683. 45. Haudrère, Les Compagnies des Indes orientales, 554-555. According to Magon, the pacotille carried out by ship's captains was "enormous": ANOM, COL/C4/9, without folio, Magon's personal journal, January 27, 1756. 
established in the Austrian Netherlands intending to protect them against France. ${ }^{46}$ Finally, the Dutch government opted for neutrality, a position much welcomed by the VOC which was suffering from a commercial slump. There was even some speculation during the war that the VOC might combine with the French Compagnie to oppose the English. ${ }^{47}$

Even before the beginning of the Seven Years War, the French Mascarenes faced acute food shortages due to disturbances in Madagascar, notably internecine strife between 1750 and 1765, and frequent locust swarms that devastated crops along the east coast of the island. ${ }^{48}$ At the same time, warfare between the French and English on the Indian peninsula reduced traditional supplies of rice and cattle to the Mascarenes. ${ }^{49}$ Additionally, Bourbon produced insufficient food for the Île de France and the French navy. It was in these circumstances that governor Magon noted: "the difficult situation in which I find myself, and the pressing need that I have to draw help from all quarters in order to secure the life of my men and for whom I will have to find subsistence, has galvanized me" to send the ship St. Charles from Port Louis to the Cape (it sailed on 3 February 1756). ${ }^{50}$ Magon wrote to Tulbagh, the governor at the Cape, asking him to authorize the French captain of the St. Charles to buy 80 to 90 last $^{51}$ of wheat for the islands. This request was highly unusual. According to the Politieke Raad ("Council of Policy") at the Cape, only two similar requests had been made by foreigners: that of the vessel the Triton in 1743, demanding wine, and that of three English Indiamen in 1752 requesting wheat to take to Bengal. ${ }^{52}$ The Mascarene authorities also searched for other sources of provisions, sending expeditions to Queda, ${ }^{53}$ Batavia, ${ }^{54}$ and Rio de Janeiro. ${ }^{55}$ However, due to its proximity and plentiful supplies, the Cape remained their most important source of wheat, and Madagascar their most important source of rice and livestock, throughout the conflict. During the first five years of his administration, Rijk Tulbagh (1699-1771), governor of the Cape from 1751 to 1771, celebrated the centenary of the foundation of the colony, and witnessed an increase in the number of French vessels calling at the port. Further, he

46. Alice C. Carter, The Dutch Republic in Europe in the Seven Years' War (Florida: University of Miami Press, 1971), 34.

47. ANOM, COL/C5B/1, piece 1, Mondion to Secret Committee of the Indies, Cape of Good Hope, February 24, 1759.

48. Jane Hooper, "Flux du sang et sauterelles: How the People and Environment of Madagascar Thwarted French Commercial Expansion", Proceedings of the Western Society for French History, 37 (2009): 49-50. 49. ANOM, COL/C4/8, without folio, Lozier-Bouvet to the Directors of the Compagnie, Île de France, January 10, 1754.

50. ANOM, COL/C4/9, without folio, Magon's personal journal, January 27, 1756.

51. One last equals 1250 kilograms.

52. WCA, C135, f. 185-221, Resolution of the Council of Policy, April 26, 1757.

53. ANOM, COL/C4/9, without folio, Magon's personal journal, June 15, 1756.

54. ANOM, COL/C4/9, without folio, Magon's personal journal, August 5, 1756; ANOM, COL/C4/12, without folio, Desforges-Boucher's personal journal, October 30, 1760.

55. ANOM, COL/C4/12, without folio, Desfores-Boucher's personal journal, March 14, 1760. 
received visits from French officials, Pierre Félix Barthélémy David (1711-1795), governor of the Mascarenes from 1750 to 1752, and Joseph François Dupleix (1697-1763), governor of Pondicherry from 1742 to 1754, both of whom he treated with much honour. In line with the policy of neutrality proclaimed by the Dutch Republic and the VOC, Tulbagh assisted both English and French vessels in need of provisions, although he especially encouraged trading opportunities with the French islands. As a result, he enjoyed considerable popularity with both settlers at the Cape and French administrators on the Mascarenes, and the Cape economy experienced a significant fillip during the Seven Years' War. ${ }^{56}$ The good relations established between the Cape and the Mascarenes is reflected in the diplomatic courtesy expressed by René Magon de la Villebague (1722-1778), governor of the Mascarenes from 1755-5957 and his successor, Antoine Desforges-Boucher (17151795), ${ }^{58}$ when writing to request provisions from the Dutch. In addition to the plants and seeds with which Magon tried to gain the goodwill of Tulbagh, he also regularly sent him bottles of vin de Champagne. In return, Tulbagh sent multiple quintals of vin de Constance ${ }^{59}$ - both red and white - to Port Louis. ${ }^{60}$ It is uncertain if these gifts proved decisive in securing Tulbagh's cooperation, but a good relationship between the governors of the two colonies was maintained throughout the war, and when Desforges-Boucher relieved Magon in 1759, he wrote:

Sir, I would be very pleased to cooperate with you in order to perpetuate the good understanding between our two nations, and especially to be able to show you the esteem I have for your person, and how much I desire the opportunities to please and serve you. ${ }^{61}$

Again, in December 1761 Desforges-Boucher referred in his diary to Tulbagh as "a gallant man who served us to his utmost during this war." ${ }^{62}$ However, Tulbagh was bound by orders from the Heren XVII, and when they heard that during the

56. Bernard, Afrique hollandaise, 158; George McCall Theal, History of South Africa under the Administration of the Dutch East India Company, 1652 to 1795 (London: S. Sonnenschein \& Co. Ltd., 1897), 2: 88-89.

57. Subsequently he was intendant of the Caribbean Island of St. Domingue between 1763 and 1766. Afterwards he returned to Port Louis where he died in 1778.

58. He was the son of Antoine Desforges-Boucher, governor of Bourbon between 1723 and 1725. He served as governor of the Mascarenes from 1759 to 1766 . He retired to his estate in Gol (île de France) where he died in 1795 .

59. Constantia is still a famous vineyard in the Western Cape. One quintal equals approximately fifty kilograms.

60. For example, WCA, C652, without folio, Magon to Tulbagh, Île de France, November 6, 1758.

61. WCA, C652, without folio, Desforges-Boucher to Tulbagh, Île de France, November 6, 1759.

62. ANOM, COL/C4/12, without folio, Desfores-Boucher's personal journal, December 14, 1761. 
siege of Madras in 1758, the French commander Lally had confiscated the VOC ship Haarlem and seized the Dutch factory in Sadras, near Pondicherry, they forbade the Cape governor to sell company wheat and wine to the Mascarene authorities. ${ }^{63}$ This, of course, placed constraints upon the Cape governor, but we have reason to believe that he continued to help the French. Moreover, contact between the governors of the two islands lasted beyond the administrative terms of the governorships of the Cape and Mascarenes. In 1768, for example, Tulbagh invited Desforges-Boucher, two years after the end of his governorship, to visit the Cape - an invitation accepted by the Frenchman who wanted to see the "magnificent colony" of his friend to whom he again expressed gratitude for his assistance during the war. ${ }^{64}$

\section{ON THE BRINK OF FAMine}

Although by the mid-eighteenth century the Mascarenes occasionally produced agricultural surpluses with which to provision passing ships ${ }^{65}$ cyclones, droughts, and vermin such as rats, birds, and locusts ensured that they continued to suffer frequent food shortages. ${ }^{66}$ Thus Rose Pinsczon du Sel wrote in September 1757 that "this wonderful world has no money, provisions or munitions." ${ }^{67}$ On multiple occasions, Magon informed the Compagnie directors that he urgently needed all kinds of provisions from Europe in order to "avoid dying of hunger", 68 as well as military supplies. Compagnie ships and naval squadrons that regularly called at Port Louis drew heavily on available local stocks that proved of vital importance. Thus, although in October 1757, Magon expressed his fear that it would be impossible to feed the 7000 sailors and soldiers whose arrival was anticipated, ${ }^{69}$ early in 1758 the Hermione arrived at Port Louis from the Cape loaded with 713,000 pounds of wheat. ${ }^{70} \mathrm{Had}$ it not, the islands would have had to have subsisted on corn and manioc. ${ }^{71}$

However, the situation became critical again later the same year due to the presence of the French squadron under the command of Anne Antoine, Comte d'Aché (17011780) who, unlike the governor who was under Compagnie orders, answered directly to

63. WCA, C139, f. 235-245, Resolution of the Council of Policy, May 19, 1761.

64. Archives départementales du Morbihan (hereafter ADM), E2227, without folio, Desforges-Boucher to Tulbagh, Gol, November 2, 1768.

65. Gwyn Campbell, "Imperial Rivalry in the Western Indian Ocean and Schemes to Colonize Madagascar (1769-1826)," in Afrikanische Beziehungen, Netzwerke und Räume, ed. Laurence Marfaing \& Brigitte Reinwald (Münster: Lit Verlag, 2001) 111-130

66. See ANOM, COL/C4/19, f. 167, Journal of Pierre Poivre, October 5, 1767.

67. Boisanger \& La Bourdonnaye- Blossac, Fortune des isles, 129.

68. Archives nationales (hereafter AN), M1198, f. 237-238, Magon to the Secret Committee of the Indies, Île de France, November 7, 1758.

69. ANOM, COL/C4/10, without folio, Magon's personal journal, October 11, 1757.

70. One Parisian pound equals 489.5 grams.

71. ANOM, COL/C4/10, without folio, Magon's personal journal, March 22, 1758. 
the crown and had priority over maritime affairs. ${ }^{72}$ As locally produced and imported provisions proved insufficient to supply both the naval squadron and local settlers, d'Aché finally agreed in the autumn of 1758 to send eight ships with 4,500 sailors and soldiers to the Cape in order to relieve the burden on the French islands. The fleet returned in 1759 with almost 2 million pounds of wheat, enabling d'Arché to sail the squadron to the French post of Pondicherry. ${ }^{73}$

However, relief was temporary on the Mascarenes where in January 1760 a violent cyclone ruined most crops and destroyed or damaged many naval vessels. ${ }^{74}$ Also, the French, who had lost all their possessions in Bengal, were forced to abandon the siege of Madras, and soon Pondicherry found itself besieged by the English. This pushed governor Desforges-Boucher into renouncing his intention of sending two more ships to the Cape as "their desolate state would send a signal to the English that the French fleet was in no situation to send help to the Indian peninsula." ${ }^{75}$ In addition, the government had to feed nearly 9,000 people (4,217 residents and 4,758 sailors) - 6,500 of whom required an estimated 228,240 pounds of bread every month. ${ }^{76}$ Although Desforges-Boucher dispatched six ships sent to the Cape in 1761, only two brought back provisions surplus to the immediate needs of the fleet. ${ }^{77}$ The following table indicates the goods that were obtained at the Cape ${ }^{78}$ :

\begin{tabular}{|c|c|c|c|c|c|c|c|c|c|c|c|c|}
\hline Ship & Wheat & Flour & Biscuits & $\begin{array}{c}\text { Red } \\
\text { Wine }\end{array}$ & $\begin{array}{c}\text { White } \\
\text { Wine }\end{array}$ & $\begin{array}{c}\text { Eau-de- } \\
\text { vie }\end{array}$ & Arak & $\begin{array}{c}\text { Salted } \\
\text { beef }\end{array}$ & Butter & Cheese & Candles & Peas \\
\hline Vengeur & - & 12,726 & 114,150 & 35 & 335 & 40 & 26 & 19,240 & 4,160 & 190 & - & - \\
\hline Centaure & - & 17,291 & 83,976 & - & 270 & 25 & 38 & 33,555 & 4,142 & - & - & - \\
\hline Lys & 500,000 & 49,766 & 234,103 & 45 & 363 & 222 & - & 24,383 & 3,648 & 429 & 513 & 8,640 \\
\hline Gange & 900,000 & - & - & - & - & - & - & - & 2,923 & 47 & 5,487 & - \\
\hline Total & $1,400,000$ & 79,783 & 432,229 & 80 & 968 & 287 & 64 & 77,178 & 14,873 & 666 & 6000 & 8640 \\
\hline
\end{tabular}

Table 1. Goods bought from Cape of Good Hope by French Ships in 1760

When the VOC directors forbade Tulbagh to trade wheat from the company granaries, the Cape inhabitants provided some relief. For example, in 1761, an agreement was concluded between the French and a certain Jan Vogel for the delivery of wheat and

72. For example, ANOM, COL/C4/12, without folio, Desforges-Boucher's journal, January 20, 1760.

73. ANOM, COL/C4/10, without folio, Deliberation of the Council of Île de France, November 2, 1758.

74. ANOM, COL/C4/12, without folio, Desforges-Boucher's personal journal, January 28, 1760.

75. ANOM, COL/C4/12, without folio, Desforges-Boucher's personal journal, February 17, 1760.

76. ANOM, COL/C4/12, without folio, Desforges-Boucher, État de la consommation, Port Louis, June 10,1760 . The residents consisted of 2317 slaves and free blacks, 1100 soldiers of the garrison, 300 workers in the port, and 500 inhabitants without resources.

77. ANOM, COL/C4/12, without folio, Desforges-Boucher's personal journal, April 9, 1761.

78. Source: ANOM, COL/C4/10, without folio, Babinet, État des achats fait au Cap de Bonne Espérance, November 4, 1760 
flour. ${ }^{79}$ Again, the following year, Otto Luder Hemmy supplied the French with provisions, albeit with great difficulty and at high prices ${ }^{80}$ According to historian George Theal, the arrival of the French squadron in 1758-59 doubled or even tripled the price of wheat which, in 1760, increased to 10 livres per 100 pounds. ${ }^{81}$ This trade was highly advantageous to residents of the Cape who, between the 1750s and 1770s, experienced abundant harvests and surplus wheat stocks, which caused prices paid by the VOC to remain stagnant. ${ }^{82}$

\begin{tabular}{|c|c|c|}
\hline Year & Number & Supplies of wheat (in pounds) \\
\hline 1756 & 1 & 200,000 \\
\hline 1757 & 1 & 300,000 \\
\hline 1758 & 1 & 700,000 \\
\hline 1759 & 6 & $1,900,000$ \\
\hline 1760 & 4 & $1,400,000$ \\
\hline 1761 & 2 & $2,000,000$ \\
\hline 1762 & 2 & 300,000 \\
\hline 1763 & 3 & unknown \\
\hline Total & 20 & $6,800,000$ \\
\hline
\end{tabular}

Table 2. Number of French ships calling at the Cape for provisions to supply the Mascarenes ${ }^{83}$

During the Seven Years' War, around one-fifth (20 out of 105) foreign vessels calling at the Cape were French ships supplying the Mascarenes. ${ }^{84}$ The French obtained at least 6.8 million pounds of wheat from the Cape, or an annual average of nearly one million pounds, without taking into account supplies delivered to warships calling at the Cape. Moreover, the figures in Table 1 exclude significant quantities of flour and biscuits, highly important commodities for the Mascarenes given that Bourbon Island during this period could provide a maximum of only 600,000 pounds of wheat in a year characterized by a good harvest. ${ }^{85}$ Moreover, Cape grain, which usually consisted of "old wheat" from previous harvests, was preferred by settlers on the Mascarenes as it produced about 30

79. ANOM, COL/C5B/1, piece 7, Contract between Surville \& Vogel, 1761.

80. ANOM, COL/C5B/1, piece 12, St. Martin to the Secret Committee of the Indies, Cape, May 17, 1762. 81. Theal, History of South Africa, 88; ADM, E2227, without folio, Desforges-Boucher to Bouvet, Port Louis, August 28, 1760.

82. Bernard, Afrique hollandaise, 138-139. They could even sell wheat from the previous harvests for $81 / 2$ guilders a mud. One mud equals 111.5 metric liters. WCA, C138, f. 55-74, Resolution of the Council of Policy, January 8, 1760.; Van Duin \& Ross, Economy of the Cape Colony, 40.

83. Sources: WCA, C2006-2021, Journal of the Cape (1756-1763); ANOM, COL/C4/9-13, Correspondence with Île de France; ANOM, COL/C5B/1, Correspondence with Cape of Good Hope.

84. Van Duin \& Ross, Economy of the Cape Colony, 127.

85. ANOM, COL/C5B/1, piece 8, Surville to Secret Committee of the Indies, Cape of Good Hope, January $30,1762$. 
percent more flour than their own wheat. ${ }^{86}$

At the same time, wine became the second most important export from the Cape to the Mascarenes, cut off by hostilities from European supplies of wine. As early as 1756, Magon bemoaned the fact that the officers of the St. Charles had not used their remaining stock of silver coins to buy Cape wine. ${ }^{87}$ In 1761, nearly 20,000 litres were shipped from the Cape to the Mascarenes aboard the French ship Mauras.$^{88}$ In addition, as a duty existed on the private sale of wheat, wine and brandy to strangers, the VOC did not oppose this particular trade as long as their own ships and settlements were well supplied. Indeed, between 1759 and 1761, when they had surplus stocks, inhabitants of the Cape gained a profit of 4,402 guilders on the wheat they sold. ${ }^{89}$ Further, the Cape helped supply Mascarene demand for a variety of European products including construction wood and naval equipment (see Table 4). The renowned botanist, Jean Baptiste Christophore Fusée-Aublet (1720-1778), commanded by the Compagnie to establish a pharmacy and botanical garden on the Mascarenes, even demanded that ships from the Cape should bring vine plants and fruit trees to be planted locally.

\begin{tabular}{|l|l|l|}
\hline 299,700 pounds of wheat & 20,000 pounds of sheep fat & 3,000 glass squares \\
\hline 37,000 pounds of fine flower & 21,000 pounds of butter & 1,850 pairs of soldiers' shoes \\
\hline 80,400 pounds of rough flour & 4,984 pounds of copper plates & 8,400 Flemish knives \\
\hline 107,000 pounds of biscuits & 220 pounds of tin welding & 12,580 pounds of nails \\
\hline $81^{3 / 4}$ leggers $^{91}$ of arak & 300 pounds of copper welding & 2,000 packets of rattan \\
\hline 60,374 pounds of salted beef & 1,083 pounds of sewing thread & $\begin{array}{l}3,800 \text { of twill for soldiers' } \\
\text { use }\end{array}$ \\
\hline $\begin{array}{l}\text { 24,280 pounds of salted } \\
\text { mutton }\end{array}$ & $\begin{array}{l}480 \text { pieces of blue tissue } \\
\text { from Holland for soliders } \\
\text { use }\end{array}$ \\
\hline 6,380 pounds of salted lard & 1,050 hats & \begin{tabular}{l}
10,000 pounds of candles \\
\hline
\end{tabular}
\end{tabular}

Table 3. The Cargo of the Conde in $1762 .{ }^{91}$

Thus wheat from the Cape saved the Mascarenes from famine. More importantly, wheat was the staple food for Europeans who used it to make bread and biscuits. In the IOW, rice and corn were more readily available than wheat. However, they were used

86. ANOM, COL/C4/9, without folio, Magon's personal journal, April 4, 1757.

87. ANOM, COL/C4/9, without folio, Magon's personal journal, March 19, 1757.

88. ANOM, COL/C4/13, without folio, Desforges-Boucher's personal journal, March 12, 1761.

89. Van Duin \& Ross, Economy of the Cape Colony, 164. Although not mentioned, it seems reasonable to think that it was to the passing French ships.

90. One legger equals one barrel of 563 litters.

91. ANOM, COL/C5B/1, piece 12, Cargo of the Condé, March 30, 1762. 
almost exclusively to feed African and Asian slaves, sepoys, and lascars. Consequently, Europeans, especially soldiers and sailors not familiar with the East Indies, considered rice and corn as of "lower" status to wheat and insisted on being supplied with bread. ${ }^{92}$ Nevertheless, local authorities tried to induce their European troops to eat other types of grain and, in 1758, decided that every sailor would receive, on a daily basis, bread made from a mixture of wheat and corn, and a portion of rice. ${ }^{93}$ The sailors and soldiers resisted the measure, Desforges-Boucher noting that it was impossible to contain the garrison "whose fear of being deprived of bread was greater than that of a military invasion." 4

In sum, Cape wheat was essential for the survival of the Mascarenes despite their access to other sources of provisions, ${ }^{95}$ notably Madagascar which supplied substantial quantities of rice and cattle. ${ }^{96}$ Cape wheat also played a decisive role in provisioning French fleets in the Indian Ocean, during the Seven Years' War, including d'Achés naval squadron ${ }^{97}$ which ensured that the Mascarenes, the only Indian Ocean territory remaining in the hands of the French after the fall of Pondicherry in 1761, possessed the soldiers and ships needed to defend themselves. It is also possible that the Dutch provisions underscored some French military initiatives, such as the capture in 1760, by Charles Hector d'Estaing (1729-1794), of English forts on Sumatra. ${ }^{98}$

\section{COMMERCiALUPHEAVAL}

The Cape authorities initially forbade trade with the Mascarenes but, because of their neutral status during the Seven Years War, they responded positively to the opportunity then presented by growing French demand for provisions. The French sought chiefly wheat and wine at the Cape, purchased with cash or exchanged for ebony wood and coffee. In 1756, for instance, the St. Charles carried ebony on its second voyage to the Cape ${ }^{99}$ where, four years later, 300 ebony logs, weighing 30,000 pounds, were bought for 350 Spanish piastres. ${ }^{100}$ Again, coffee beans formed the basis of an important trade as most French ships that

92. Sepoys and lascars were, respectively, native soldiers and sailors from the Indian subcontinent, employed in service of a European power in the $18^{\text {th }}$ century.

93. ANOM, COL/C4/10, without folio, Monteil, Règlement pour la subsistance des équipages, Île de France, October 18, 1758.

94. ANOM, COL/C4/13, without folio, Desforges-Boucher's personal journal, November 8, 1761.

95. ADM, E2227, without folio, Desforges-Boucher to Bouvet, Port Louis, October 22, 1760.

96. ANOM, COL/C4/12, without folio, Mondion to the Directors of the Compagnie, Port Louis, December 20, 1760.

97. AN, M 1198, f. 233-234, Magon to the Directors of the Compagnie, Île de France, September 21, 1758 .

98. Service historique de la Défense à Vincennes, SH 375, piece 2, Relation de la prise de tous les forts anglais de la côte de Sumatra par le brigadier Comte d'Estaing.

99. ANOM, COL/C4/9, without folio, Magon's personal journal, October 25, 1756.

100. WCA, C138, f. 112-154, Resolution of the Council of Policy, January 20, 1760. 
sailed from Port Louis called at Bourbon Island, the regional centre of coffee production.

As ongoing hostilities prevented the Compagnie from ensuring a secure maritime trade route between the Indian Ocean and France, Mascarene planters sought the opportunity to sell their produce via naval officers visiting the neutral Cape. This first happened on the second voyage of the St. Charles in 1757, when officers offloaded and sold 100 bales of coffee. Four years later, 424,000 pounds of Bourbon coffee were offloaded there. ${ }^{101}$ From 1761-3, the Heren XVII expressly demanded that the Cape authorities buy significant quantities of coffee and ebony wood from passing French ships, as they could sell both commodities in the United Provinces for a markup of 150 percent. ${ }^{102}$ For the Mascarene authorities, this illicit trade was equally important because through it they could obtain cash, as in 1761, when the Condé sold 80,000 pounds of coffee for 6000 Spanish piastres which could be used to obtain more wheat, or rice from Madagascar. ${ }^{103}$ In 1758, the French still had enough financial resources to send Commander Ruis to the Cape with a significant sum of money to buy provisions. ${ }^{104}$ Cash, however, was becoming increasingly rare. Two years later, the Gange sailed to the Cape with 20,000 Spanish piastres, which accounted for "almost all our remaining funds." 105 This represented a major difficulty for the French, as the Dutch accepted only silver coins in exchange for provisions. ${ }^{106}$ At the same time, Magon explained the problems that came with a lack of cash: "the little money that circulates in the colony will soon be exhausted. There will then remain no resource other than the Cape, if the Dutch wish to trade entirely in bills of exchange." 107 Therefore, during the 1760s, the French were obliged to use bills of exchange, which were backed by Compagnie funds. ${ }^{108}$ The problem with these bills was that, in order to ensure credibility and compete with foreign traders - such as the English whose vessels called at the Cape - the Dutch demanded for them a high rate of interest

101. WCA, C652, without folio, Tulbagh to Magon, Cape of Good Hope, January 8, 1757; ANOM, COL/ C4/14, f. 5., Desforges-Boucher to the Directors of the Compagnie, Île de France, September 20, 1762. 102. Arsip Nasional Republik Indonesia (hereafter ANRI), VOC 1031, f. 1414, Resolution of the Supreme Government, Batavia, September 22, 1761.

103. WCA, C140, f. 12-136, Resolution of the Council of Policy, February 16, 1762; WCA, C142, f. 93-137, Resolution of the Council of Policy, February 14, 1764; WCA, C140, f. 189-193, Resolution of the Council of Policy, March 16, 1762.

104. ANOM, COL/C4/10, without folio, Declaration of the Marine Council, Port Louis, November 24, 1758.

105. ANOM, COL/C4/12, without folio, Desforges-Boucher's personal journal, December 31, 1759.

106. For example, WCA, C135, f. 436-454, Resolution of the Council of Policy, December 13, 1757.

107. Bibliothèque Villon, Fonds Montbret, 866, pièce 4, Magon, Réflexions sur l’état présent de l’Isle de France, November 1760.

108. These bills of exchange could thus be transformed in cash upon exchanging them at the financial headquarters of the Compagnie des Indes. ANOM, COL/C4/13, without folio, Desforges-Boucher's personal journal, December 14, 1761. 
(8 percent). ${ }^{109}$ At the same time, the French depended upon the cooperation of Otto Luder Hemmy and Johan Christian Vogel, the richest Cape inhabitants, who - luckily for them - embraced this commercial opportunity with both hands. Without them, it would have been very difficult for the French to find enough provisions to last the war. ${ }^{110}$ The intensified exchanges between the two colonies also resulted in some friction, due to the quasi-permanent presence of some 3,500 Frenchmen at the Cape. This was the first time that a large foreign naval squadron had taken shelter in Table Bay. Its arrival nearly tripled the Cape's 2,000-odd resident white male population. ${ }^{111}$ Even though the French soldiers and sailors spent much of their wages in taverns, and officers paid handsomely for being housed by local inhabitants, they could also be a nuisance to public order. Much depended on the attitude of the French commanding officers, as discipline among the troops was often lax, especially in the 1760s, and some deserted. However, the Cape authorities were more concerned about the defection of VOC soldiers to the French ${ }^{112}$ which, always a minor concern, became common with the increase in the number of French warships. ${ }^{113}$

Such was the growth in their trade and increase in their troop presence that the French decided to appoint official agents to the Cape. Thus between 1759 and 1764, special commissaries, such as Mondion, Babinet, Surville, and St. Martin, arrived primarily to supervise funds and the provisioning of French ships. ${ }^{114}$ Their role was important as they could more easily obtain important quantities of provisions, and secure silver coins which could be used to pay the garrison and acquire provisions from Madagascar. ${ }^{115}$

\section{Aftermath}

As was the case in the French Caribbean, where free trade was revoked as soon as the war ended, French trade with the Cape slackened, despite continued high Mascarene demand for provisions. ${ }^{116}$ This change was probably provoked by the growing financial problems of the Compagnie that forced it first to relinquish control of the two Mascarene islands to

109. ANOM, COL/C5B/1, f. 15, St. Martin to the Secret Committee of the Indies, Cape of Good Hope, May 26, 1762.

110. ANOM, COL/C5B/1, piece 1, Mondion to Secret Committee of the Indies, Cape of Good Hope, March 17, 1759.

111. In 1760, there were 1354 VOC employees (including the garrison) and 697 white male adults living in the immediate surroundings of the Cape: Van Duin \& Ross, Economy of the Cape Colony, 112-117.

112. WCA, C652, without folio, Tulbagh to Massiac, Cape of Good Hope, 1758.

113. ANOM, COL/C4/12, without folio, Desforges-Boucher's personal journal, May 6, 1761.

114. See e.g. WCA, C2014, without folio, Journal of the Cape Castle, February 13, 1760; ANOM, COL/ C4/12, without folio, Desforges-Boucher's personal journal, January 8, 1760.

115. WCA, C138, f. 494-499, Resolution of the Council of Policy, December 16, 1760; ANOM, COL/ C4/13, without folio, Desforges-Boucher's personal journal, December 14, 1761; ANOM, COL/C4/12, without folio, Babinet to the Secret Committee of the Indies, April 11, 1760.

116. WCA, C652, Desforges-Boucher to Tulbagh, Île de France, December 28, 1766. 
the Crown in 1766, and finally to dissolve in 1769. Direct correspondence between the governors of the Cape and the Mascarenes also declined - albeit with a brief revival from 1768-9 due to the arrival in Bourbon of the VOC ship, Asia, seeking shelter after surviving a major storm. ${ }^{117}$ An occasional trade was maintained in coffee beans from Bourbon to the Cape, but while the French government granted liberty of trade to French subjects in the Indian Ocean region, food exchanges with the Cape remained minimal - possibly due to the fact that the Compagnie's bills of exchange were not honoured after the war due to lack of funds. ${ }^{118}$ For the French, this was reason enough to send an agent to the Cape, who was primarily employed to assure the refreshing of passing French ships, to try to revive commercial relations between the two colonies. ${ }^{119}$ From 1768 , this role was fulfilled by Jean Joseph Amat named French "naval agent at the Cape," who in 1771 was replaced by Adrien Louis Percheron de Mouchy. ${ }^{120}$ Despite the protests of Pecheron, the French bills of exchange so necessary to purchase Cape provisions for the Mascarenes, were still not being honoured almost a decade after the end of the war. ${ }^{121}$ In a context in which the dishonouring of such bills has completely discredited the French at the Cape, "to the point that we cannot for long depend upon the help we obtain" from the Cape, it was regarded as a "miracle" that the ship, Marie Adeläide, was able to purchase a million pounds of wheat. ${ }^{122}$

In the War of American Independence (1778-83), the Indian Ocean region again became a secondary theatre of the global conflict between Britain and France. The Dutch Republic, then an ally of France, was in dire need of help. French soldiers assured the defense of the Cape, which in turn was a source of provisions, one vital for visiting French fleets and significant (notably in wheat and wine) for the Mascarenes. ${ }^{123}$ From the mid1770s, the Cape also profited as both a refreshment station and slave market, from a growing French-run slave trade between East Africa and the Caribbean. ${ }^{124}$

117. WCA, C146, f. 297-345, Resolution of the Council of Policy, December 30, 1768.

118. For example, WCA, C146, f. 102-118, Resolution of the Council of Policy, February 25, 1768.

119. ANOM, COL/C4/29, f. 63, Poivre to Ministre of Marine of the Navy, Île de France, August 31, 1771. 120. Jean-Paul Morel, "Les rapports compliqués de l'intendant Poivre avec l'agent de la Marine Jean-Joseph Amat," accessed September 30, 2015, http://www.pierre-poivre.fr. Maurice Boucher erroneously names Percheron in 1757 as the first foreign representative in the settlement, but he was only assigned in 1771; Boucher, The Cape of Good Hope and Foreign Contacts, 48.

121. ANOM. COL/C4/32, f. 7, Maillart Dumesle to the Ministre of the Navy, Cape Colony, July 6, 1772. 122. ANOM. COL/C4/33, f. 94, Ternay \& Maillart to the Minister of the Navy, Port Louis, May 16, 1773; WCA, C150, f. 452-463, Resolution of the Council of Policy, December 8, 1772.

123. BNF, Arsenal 5788, Journaux des voyages de M. Boutin depuis l'année 1782.

124. ANOM, COL/C4/40, f. 252, Bellecombe \& Chevreau to the Minister of Navy and Colonies, Cape of Good Hope, June 29, 1776.; Bernard, Afrique hollandaise, 307. 
147 An Informal French-Dutch Alliance: Trade and Diplomacy Between the Cape Colony and the Mascarenes, 1719 - 1769

\section{Conclusion}

The history of the different European companies trading in the Indian Ocean World was not exclusively one of commercial competition or military conflict, at least on a local level. Despite having very limited relations for most of the first half of the eighteenth century, the outbreak of the Seven Years' War transformed the relationship between the Dutch Cape and the French Mascarene Islands independently of decisions made in the Netherlands or France. Indeed, it resulted in durable relations between the colonies, confirmed by the installation of a permanent French representative at the Cape. Relations were maintained by French vessels that opened up a hitherto unknown private trade that enriched both Cape authorities and inhabitants. They paved the way for closer cooperation during the subsequent era of free trade from 1769, in which both colonies prospered, due chiefly to the French slave trade to the Caribbean that was maintained until the Napoleonic Wars when the two colonies merged into the same empire. 